\title{
Past, Present, and Future of Allergy in Korea
}

\author{
You-Young Kim ${ }^{1,2 *}$ \\ 'Seoul National University College of Medicine, Seoul; ${ }^{2}$ Eulji Medical Center, Seoul, Korea
} This is an Open Access article distributed under the terms of the Creative Commons Attribution Non-Commercial License (http://creativecommons.org/licenses/by-nc/3.0/) which permits
unrestricted non-commercial use, distribution, and reproduction in any medium, provided the original work is properly cited.

Korean allergology has made great progress in keeping pace with global scientific advances in spite of a short history. Outstanding academic and scientific researches have been performed in a variety of allergy fields in Korea. Epidemiologic studies revealed increasing prevalence of asthma and allergic diseases and considerable morbidity and mortality in Korea. Novel inhalant allergens such as citrus red mite and two-spotted spider mite as causes of asthma and allergic rhinitis have been discovered and reported in Korea. Bidirectional translational researches have been performed and are underway to elucidate the pathogenesis of asthma and allergy, mechanisms of airway inflammation and remodeling, and new therapeutic modalities for asthma and allergic diseases. Experimental asthma models of different phenotypes according to exposed levels of lipopolysaccharide or double-stranded RNA suggested the crucial role of the innate immunity in the development of allergic airway inflammation and a new insight for asthma pathogenesis, in which both Th1 and Th2 inflammation are involved. In the field of genetic researches, numerous genetic associations with asthma and asthma-related phenotypes, such as atopy, IgE production, and airway hyperresponsiveness, have been demonstrated in Korean population. The Easy Asthma Management (EAM) program, a computer-assisted asthma management program, is anticipated to facilitate the achievement of more successful clinical outcomes by filling the gaps between guidelines and actual practices. The Integration of these multi-disciplinary allergy research resources and translation of scientific achievements to the bedside and society will lead to better allergy and asthma control in Korea.

Key Words: Allergy; asthma; Korea

\section{INTRODUCTION}

Allergic diseases, including asthma, allergic rhinitis, atopic dermatitis, and food and drug allergies cause considerable morbidity and mortality worldwide. As lifestyles and environments have changed to become more urbanized and industrialized, the incidence and prevalence of allergic diseases has increased, and the study of allergy has become one of the most important fields in medicine. Allergy remains an important and unsolved problem for clinicians and researchers; however, the progressive development of immunology, pharmacology, and molecular biology has broadened our understanding of the mechanisms underlying allergies and has provided us a way to treat patients suffering from allergic diseases.

Although allergology was only recently introduced in Korea, Korean allergology has made great progress in keeping pace with global scientific advances. The numbers of medical doctors and researchers who investigate allergies and clinical immunology have increased and a large amount of scientific progress has been made. Along with academic progress, allergy and clinical immunology has become an indispensable department in clinical medicine. Recently, the Korean government recog-
Y in Korea
I, Korea
n Non-Commercial License (http://creativecommons.org/licenses/by-nc/3.o/) which permits
riginal work is properly cited.
cientific advances in spite of a short history. Outstanding academic and
Korea. Epidemiologic studies revealed increasing prevalence of asthma
Jovel inhalant allergens such as citrus red mite and two-spotted spider
eported in Korea. Bidirectional translational researches have been per-
rgy, mechanisms of airway inflammation and remodeling, and new ther-
models of different phenotypes according to exposed levels of lipopoly-
immunity in the development of allergic airway inflammation and a new
re involved. In the field of genetic researches, numerous genetic associ-
uction, and airway hyperresponsiveness, have been demonstrated in Ko-
r-assisted asthma management program, is anticipated to facilitate the
Then guidelines and actual practices. The Integration of these multi-disci-
to the bedside and society will lead to better allergy and asthma control
Dr. Seok-Young Kang, greatly contributed to the introduction of
allergy studies and laid the foundation of Korean allergology in
an academically barren land. He founded the Korean Academy
of Asthma, Allergy, and Clinical Immunology (KAAACI) with
several researchers and clinicians in 1972 (Fig. 1A). In 1973, the
HISTORY OF ALLERGOLOGY IN KOREA
nized the importance of allergic diseases and began to support
the prevention and control of allergic diseases. In this article, the
history of Korean allergology, advances in the research field, and
various allergy-related activities in Korea are reviewed and the
future directions of Korean allergology are discussed.

Y in Korea
I, Korea
n Non-Commercial License (http://creativecommons.org/licenses/by-nc/3.o/) which permits
riginal work is properly cited.
cientific advances in spite of a short history. Outstanding academic and
Korea. Epidemiologic studies revealed increasing prevalence of asthma
Jovel inhalant allergens such as citrus red mite and two-spotted spider
eported in Korea. Bidirectional translational researches have been per-
rgy, mechanisms of airway inflammation and remodeling, and new ther-
models of different phenotypes according to exposed levels of lipopoly-
immunity in the development of allergic airway inflammation and a new
re involved. In the field of genetic researches, numerous genetic associ-
uction, and airway hyperresponsiveness, have been demonstrated in Ko-
r-assisted asthma management program, is anticipated to facilitate the
Then guidelines and actual practices. The Integration of these multi-disci-
to the bedside and society will lead to better allergy and asthma control
Dr. Seok-Young Kang, greatly contributed to the introduction of
allergy studies and laid the foundation of Korean allergology in
an academically barren land. He founded the Korean Academy
of Asthma, Allergy, and Clinical Immunology (KAAACI) with
several researchers and clinicians in 1972 (Fig. 1A). In 1973, the
HISTORY OF ALLERGOLOGY IN KOREA
nized the importance of allergic diseases and began to support
the prevention and control of allergic diseases. In this article, the
history of Korean allergology, advances in the research field, and
various allergy-related activities in Korea are reviewed and the
future directions of Korean allergology are discussed.

Y in Korea
I, Korea
n Non-Commercial License (http://creativecommons.org/licenses/by-nc/3.o/) which permits
riginal work is properly cited.
cientific advances in spite of a short history. Outstanding academic and
Korea. Epidemiologic studies revealed increasing prevalence of asthma
Jovel inhalant allergens such as citrus red mite and two-spotted spider
eported in Korea. Bidirectional translational researches have been per-
rgy, mechanisms of airway inflammation and remodeling, and new ther-
models of different phenotypes according to exposed levels of lipopoly-
immunity in the development of allergic airway inflammation and a new
re involved. In the field of genetic researches, numerous genetic associ-
uction, and airway hyperresponsiveness, have been demonstrated in Ko-
r-assisted asthma management program, is anticipated to facilitate the
Then guidelines and actual practices. The Integration of these multi-disci-
to the bedside and society will lead to better allergy and asthma control
Dr. Seok-Young Kang, greatly contributed to the introduction of
allergy studies and laid the foundation of Korean allergology in
an academically barren land. He founded the Korean Academy
of Asthma, Allergy, and Clinical Immunology (KAAACI) with
several researchers and clinicians in 1972 (Fig. 1A). In 1973, the
HISTORY OF ALLERGOLOGY IN KOREA
nized the importance of allergic diseases and began to support
the prevention and control of allergic diseases. In this article, the
history of Korean allergology, advances in the research field, and
various allergy-related activities in Korea are reviewed and the
future directions of Korean allergology are discussed.

Y in Korea
I, Korea
n Non-Commercial License (http://creativecommons.org/licenses/by-nc/3.o/) which permits
riginal work is properly cited.
cientific advances in spite of a short history. Outstanding academic and
Korea. Epidemiologic studies revealed increasing prevalence of asthma
Jovel inhalant allergens such as citrus red mite and two-spotted spider
eported in Korea. Bidirectional translational researches have been per-
rgy, mechanisms of airway inflammation and remodeling, and new ther-
models of different phenotypes according to exposed levels of lipopoly-
immunity in the development of allergic airway inflammation and a new
re involved. In the field of genetic researches, numerous genetic associ-
uction, and airway hyperresponsiveness, have been demonstrated in Ko-
r-assisted asthma management program, is anticipated to facilitate the
Then guidelines and actual practices. The Integration of these multi-disci-
to the bedside and society will lead to better allergy and asthma control
Dr. Seok-Young Kang, greatly contributed to the introduction of
allergy studies and laid the foundation of Korean allergology in
an academically barren land. He founded the Korean Academy
of Asthma, Allergy, and Clinical Immunology (KAAACI) with
several researchers and clinicians in 1972 (Fig. 1A). In 1973, the
HISTORY OF ALLERGOLOGY IN KOREA
nized the importance of allergic diseases and began to support
the prevention and control of allergic diseases. In this article, the
history of Korean allergology, advances in the research field, and
various allergy-related activities in Korea are reviewed and the
future directions of Korean allergology are discussed.

Y in Korea
I, Korea
n Non-Commercial License (http://creativecommons.org/licenses/by-nc/3.o/) which permits
riginal work is properly cited.
cientific advances in spite of a short history. Outstanding academic and
Korea. Epidemiologic studies revealed increasing prevalence of asthma
Jovel inhalant allergens such as citrus red mite and two-spotted spider
eported in Korea. Bidirectional translational researches have been per-
rgy, mechanisms of airway inflammation and remodeling, and new ther-
models of different phenotypes according to exposed levels of lipopoly-
immunity in the development of allergic airway inflammation and a new
re involved. In the field of genetic researches, numerous genetic associ-
uction, and airway hyperresponsiveness, have been demonstrated in Ko-
r-assisted asthma management program, is anticipated to facilitate the
Then guidelines and actual practices. The Integration of these multi-disci-
to the bedside and society will lead to better allergy and asthma control
Dr. Seok-Young Kang, greatly contributed to the introduction of
allergy studies and laid the foundation of Korean allergology in
an academically barren land. He founded the Korean Academy
of Asthma, Allergy, and Clinical Immunology (KAAACI) with
several researchers and clinicians in 1972 (Fig. 1A). In 1973, the
HISTORY OF ALLERGOLOGY IN KOREA
nized the importance of allergic diseases and began to support
the prevention and control of allergic diseases. In this article, the
history of Korean allergology, advances in the research field, and
various allergy-related activities in Korea are reviewed and the
future directions of Korean allergology are discussed.

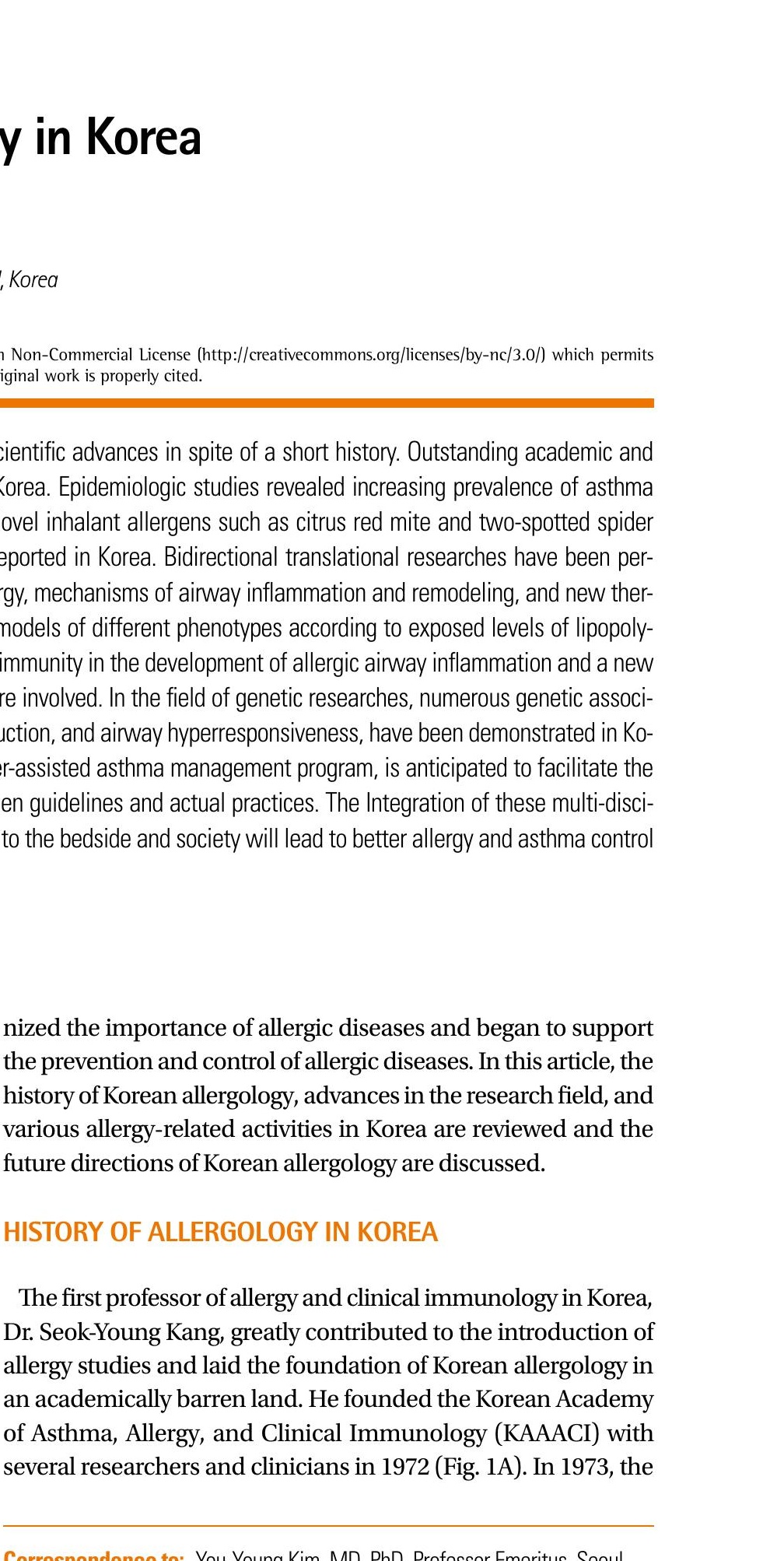

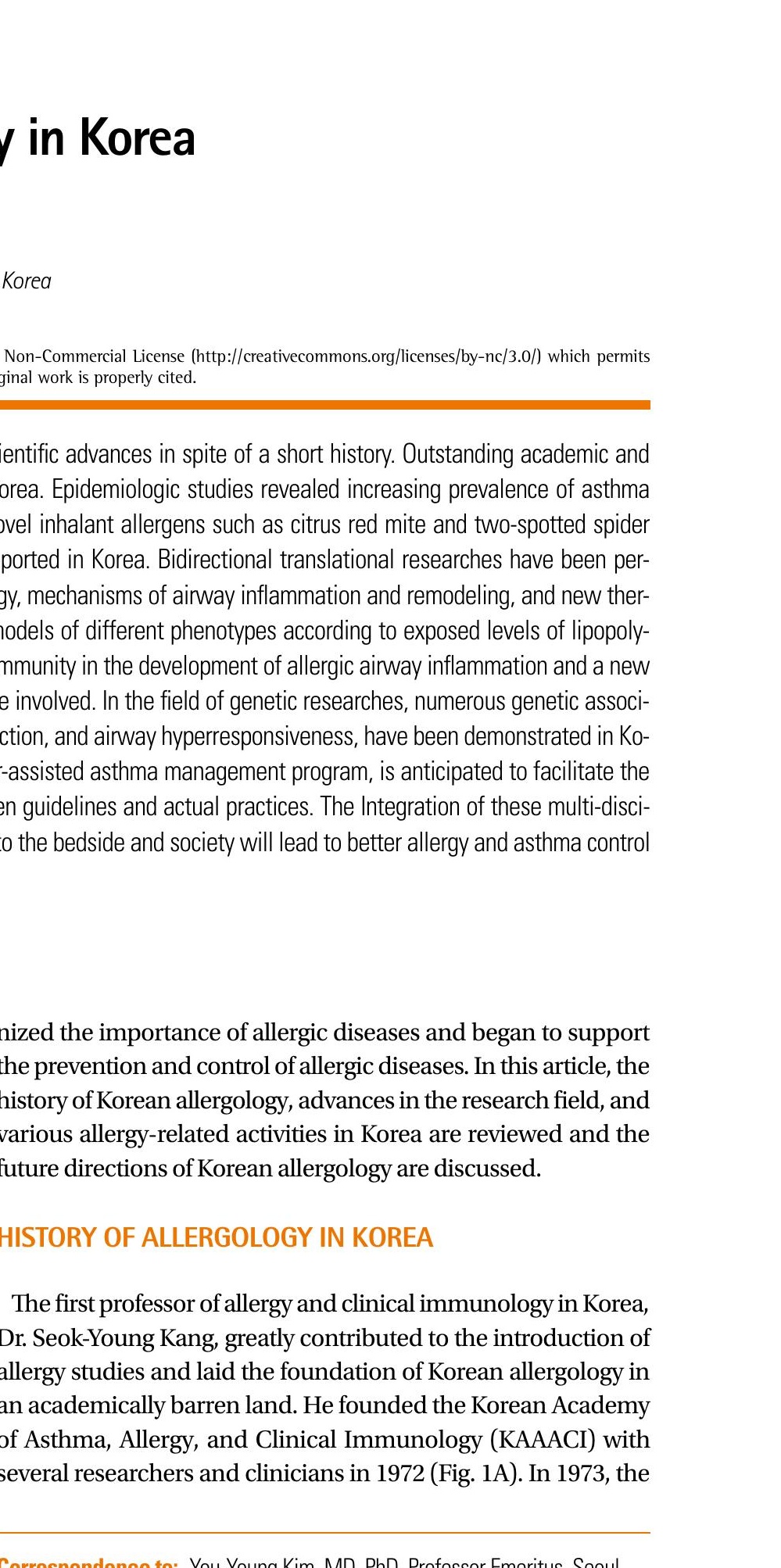

Y in Korea
I, Korea
n Non-Commercial License (http://creativecommons.org/licenses/by-nc/3.o/) which permits
riginal work is properly cited.
cientific advances in spite of a short history. Outstanding academic and
Korea. Epidemiologic studies revealed increasing prevalence of asthma
Jovel inhalant allergens such as citrus red mite and two-spotted spider
eported in Korea. Bidirectional translational researches have been per-
rgy, mechanisms of airway inflammation and remodeling, and new ther-
models of different phenotypes according to exposed levels of lipopoly-
immunity in the development of allergic airway inflammation and a new
re involved. In the field of genetic researches, numerous genetic associ-
uction, and airway hyperresponsiveness, have been demonstrated in Ko-
r-assisted asthma management program, is anticipated to facilitate the
Then guidelines and actual practices. The Integration of these multi-disci-
to the bedside and society will lead to better allergy and asthma control
Dr. Seok-Young Kang, greatly contributed to the introduction of
allergy studies and laid the foundation of Korean allergology in
an academically barren land. He founded the Korean Academy
of Asthma, Allergy, and Clinical Immunology (KAAACI) with
several researchers and clinicians in 1972 (Fig. 1A). In 1973, the
HISTORY OF ALLERGOLOGY IN KOREA
nized the importance of allergic diseases and began to support
the prevention and control of allergic diseases. In this article, the
history of Korean allergology, advances in the research field, and
various allergy-related activities in Korea are reviewed and the
future directions of Korean allergology are discussed.

Y in Korea
I, Korea
n Non-Commercial License (http://creativecommons.org/licenses/by-nc/3.o/) which permits
riginal work is properly cited.
cientific advances in spite of a short history. Outstanding academic and
Korea. Epidemiologic studies revealed increasing prevalence of asthma
Jovel inhalant allergens such as citrus red mite and two-spotted spider
eported in Korea. Bidirectional translational researches have been per-
rgy, mechanisms of airway inflammation and remodeling, and new ther-
models of different phenotypes according to exposed levels of lipopoly-
immunity in the development of allergic airway inflammation and a new
re involved. In the field of genetic researches, numerous genetic associ-
uction, and airway hyperresponsiveness, have been demonstrated in Ko-
r-assisted asthma management program, is anticipated to facilitate the
Then guidelines and actual practices. The Integration of these multi-disci-
to the bedside and society will lead to better allergy and asthma control
Dr. Seok-Young Kang, greatly contributed to the introduction of
allergy studies and laid the foundation of Korean allergology in
an academically barren land. He founded the Korean Academy
of Asthma, Allergy, and Clinical Immunology (KAAACI) with
several researchers and clinicians in 1972 (Fig. 1A). In 1973, the
HISTORY OF ALLERGOLOGY IN KOREA
nized the importance of allergic diseases and began to support
the prevention and control of allergic diseases. In this article, the
history of Korean allergology, advances in the research field, and
various allergy-related activities in Korea are reviewed and the
future directions of Korean allergology are discussed.

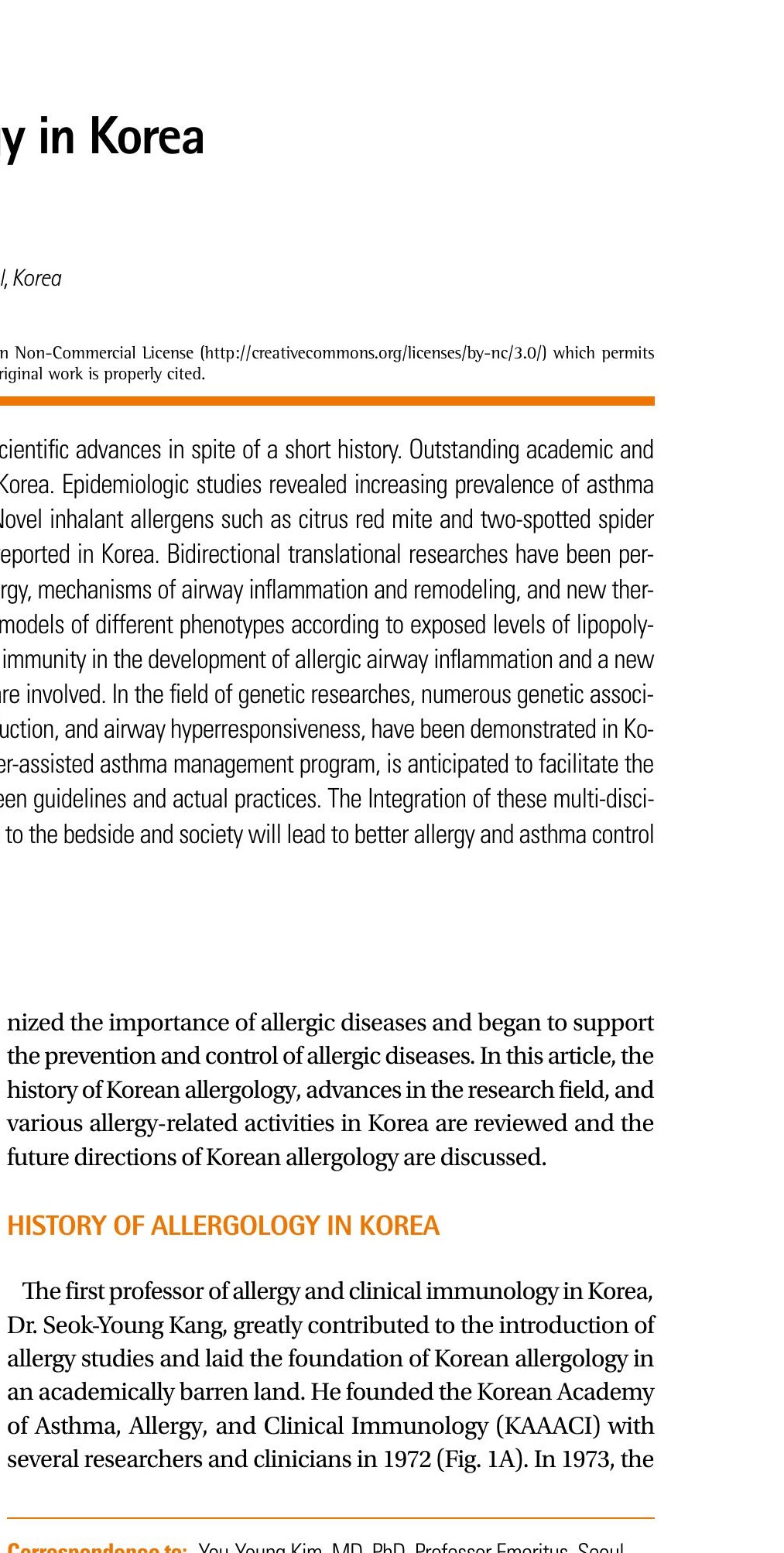

Y in Korea
I, Korea
n Non-Commercial License (http://creativecommons.org/licenses/by-nc/3.o/) which permits
riginal work is properly cited.
cientific advances in spite of a short history. Outstanding academic and
Korea. Epidemiologic studies revealed increasing prevalence of asthma
Jovel inhalant allergens such as citrus red mite and two-spotted spider
eported in Korea. Bidirectional translational researches have been per-
rgy, mechanisms of airway inflammation and remodeling, and new ther-
models of different phenotypes according to exposed levels of lipopoly-
immunity in the development of allergic airway inflammation and a new
re involved. In the field of genetic researches, numerous genetic associ-
uction, and airway hyperresponsiveness, have been demonstrated in Ko-
r-assisted asthma management program, is anticipated to facilitate the
Then guidelines and actual practices. The Integration of these multi-disci-
to the bedside and society will lead to better allergy and asthma control
Dr. Seok-Young Kang, greatly contributed to the introduction of
allergy studies and laid the foundation of Korean allergology in
an academically barren land. He founded the Korean Academy
of Asthma, Allergy, and Clinical Immunology (KAAACI) with
several researchers and clinicians in 1972 (Fig. 1A). In 1973, the
HISTORY OF ALLERGOLOGY IN KOREA
nized the importance of allergic diseases and began to support
the prevention and control of allergic diseases. In this article, the
history of Korean allergology, advances in the research field, and
various allergy-related activities in Korea are reviewed and the
future directions of Korean allergology are discussed.

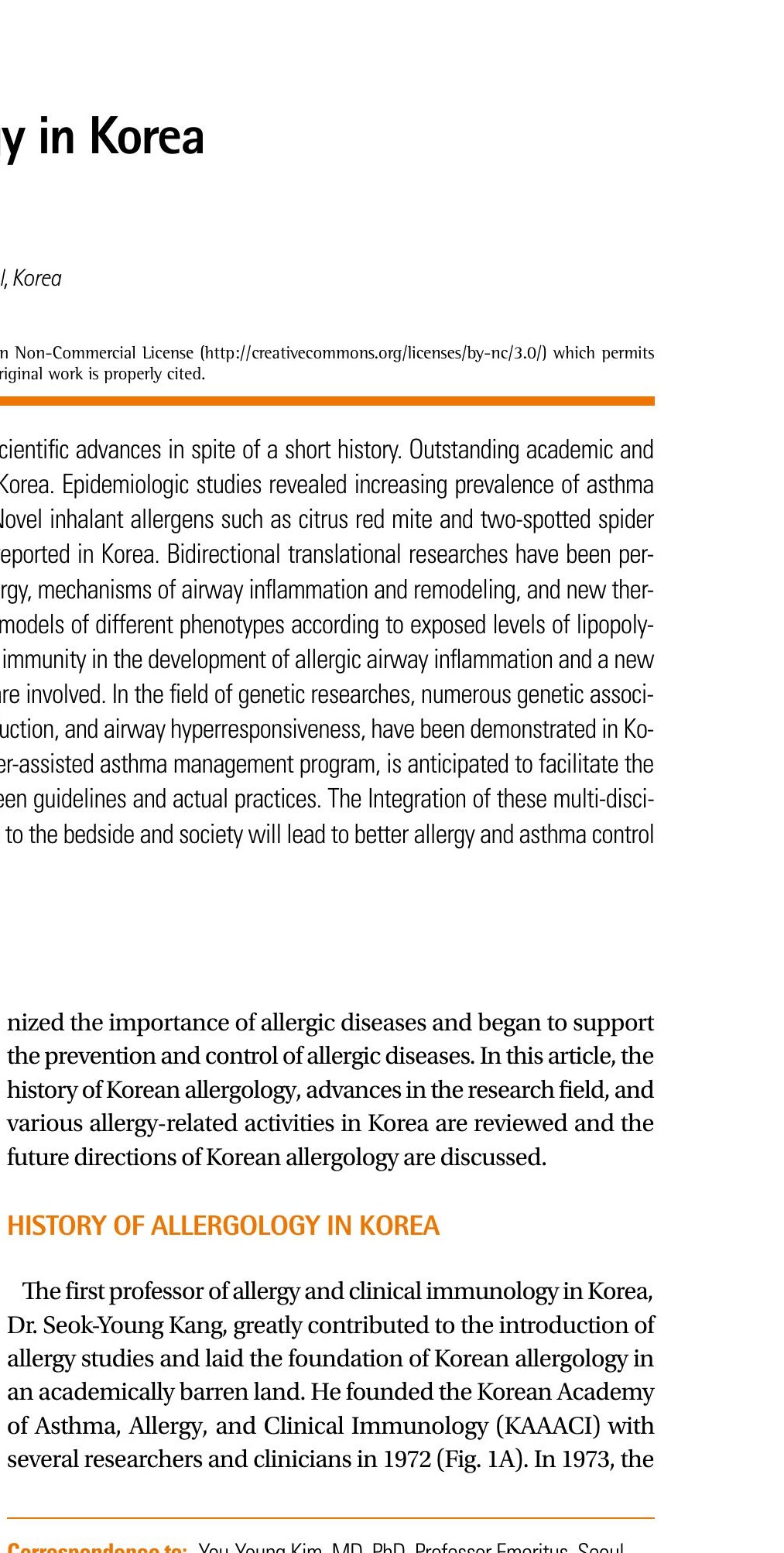

Correspondence to: You-Young Kim, MD, PhD, Professor Emeritus, Seoul National University \& Bumsuk Professor of Medicine, Eulji Medical Center, Seoul, Korea.

Tel: +82-2-970-8340; Fax: +82-2-745-0257; E-mail: youyoung@snu.ac.kr, youyoung@eulji.ac.kr

Received: March 16, 2010; Accepted: May 12, 2010

- There are no financial or other issues that might lead to conflict of interest. 
first Korean allergy congress was held on the topic of pollen allergies in Seoul. Since then, Korean allergy congresses have been held continuously in the spring and autumn biannually (Fig. 1B). The first allergy clinic was opened in Seoul National University Hospital (SNUH) in 1979 (Fig. 1C) and the allergy division in the department of internal medicine at SNUH was launched as an independent division for the first time in Korea in 1980. KAAACI joined the Korean Federation of Science and Technology Society in 1981.

In the 1980s, the most remarkable achievement of KAAACI was the publication of an official journal, "Allergy" (The Journal of The Korean Society of Allergology; Fig. 1D). The first edition of this journal was published in 1981 with three original articles, one case report, four review articles, symposium abstracts, and newsletters. Since then, the number of submissions has increased gradually and articles have encompassed the various allergy research fields including epidemiology, occupational allergy, animal experiments, molecular biology, and immunology. The name of the journal changed to "Journal of Asthma, Allergy and Clinical Immunology" in 1998 and continues to be issued quarterly. KAAACI and the Korean Academy of Pediatric Allergy \& Respiratory Disease (KAPARD) jointly inaugurated a new journal, "Allergy, Asthma \& Immunology Research" (AAIR) in October 2009. In addition to this journal, KAAACI has published various textbooks, including Allergy in 1993, Asthma and Allergic Disease in 2002, and various clinical guidebooks (e.g. Korean
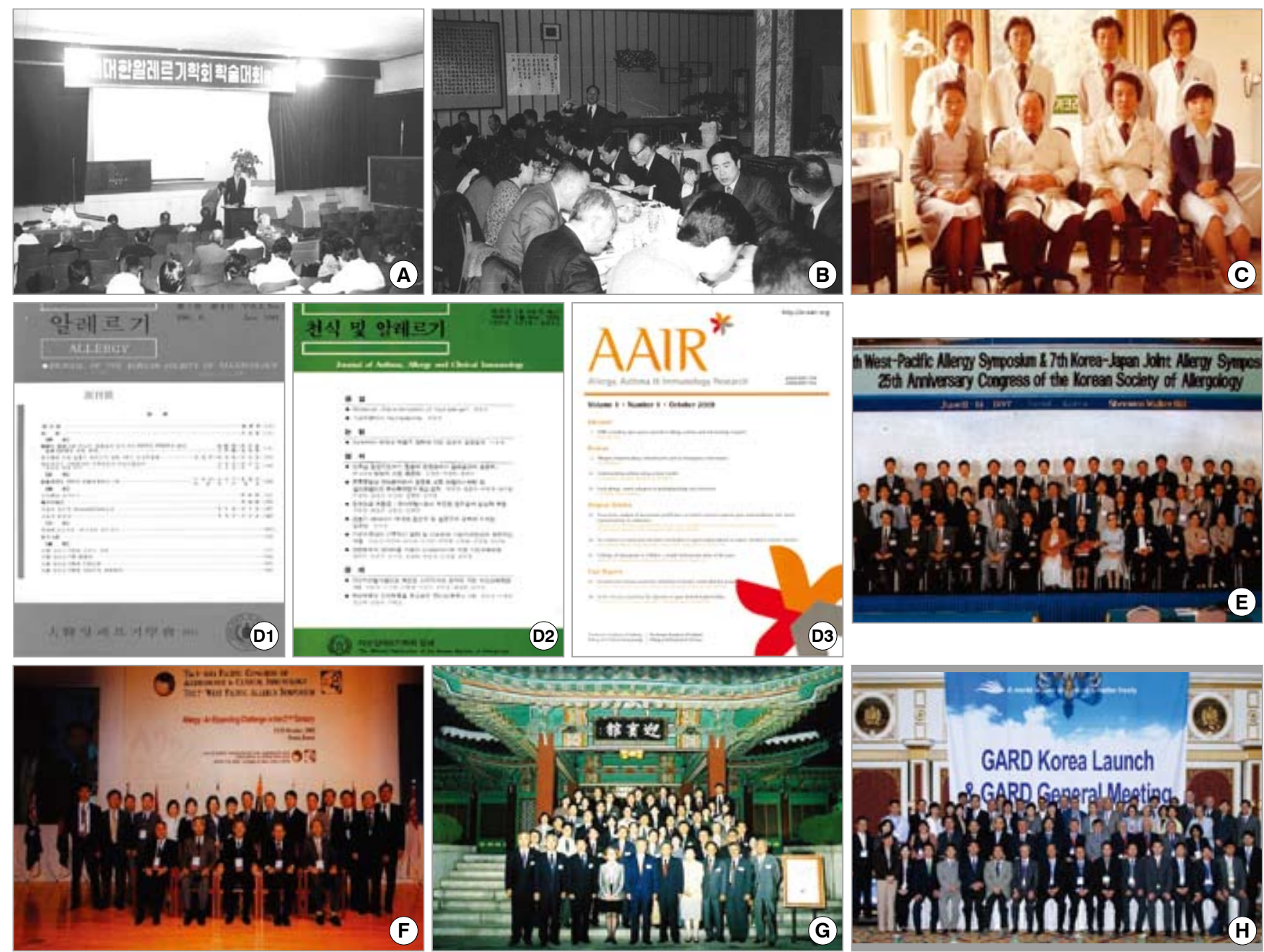

Fig. 1. Brief view of Korean allergology history. (A) The first general meeting of KAAACI (Foundation meeting: 30 November, 1972). (B) The first Korean allergy congress (8 December, 1973). (C) Professor Seok-Young Kang and early members of the first Allergy Clinic in Korea. (D) (D1) The First Edition of "Allergy" (The Journal of The Korean Society of Allergology) issued in June, 1981. (D2) The name of the journal changed to "Journal of Asthma, Allergy and Clinical Immunology" in 1998. (D3) The first edition of Asthma, Allergy \& Immunologic Research (AAIR), the international journal of KAAA Cl and KAPARD in January, 2010. E. The 5th West-Pacific Allergy Symposium (WAPS) and the 7th Korea-Japan Joint Allergy Symposium which was concurrently held with the 25th Anniversary Congress of KAAACI (June, 1997, Seoul). (F) Organizing committee members of The 5th Asian Pacific Congress of Allergology and Clinical Immunology (APCACI) and the 7th WPAS (October, 2002, Seoul). (G) The first general meeting of the Korea Asthma Allergy Foundation (KAF) (October, 2003). (H) The second Global Alliance of Chronic Respiratory Diseases (GARD) general meeting and GARD Korea launching in Seoul, Korea (May 2004). 
Asthma Treatment Guideline in 1998, Korean Allergic Rhinitis Diagnosis and Treatment Guideline in 1999, and Korean Urticaria Treatment Guideline in 2000).

KAAACI has communicated and had relationships with various international allergy societies and has held international congresses and joint symposiums successfully since the 1980s. KAAACI became the 27th member of the IAACI (WAO) in 1982. The first Korea-Japan joint symposium was held in Daegu, Korea in 1983. Under the leadership of professor Seok-Young Kang from Korea and professor Tatsushi Ishizaki from Japan, the first West Pacific Allergy Symposium (WPAS) was held in Kwangju, Korea in 1986. This symposium was the basis for the foundation of the Asia Pacific Association of Allergy, Asthma and Clinical
Immunology (APAAACI). In 1997, the 5th WPAS and the 7th Korea-Japan Joint Allergy symposium were held concurrently with the 25th Anniversary Congress of the Korean Society of Allergology (Fig. 1E). In 2000, the first Interasma North Asia/Korea Chapter was held in Seoul. In 2002, the 5th Asia Pacific Congress of Allergology and Clinical Immunology (APCACI) was held concurrently with the 7th WPAS in Seoul (Fig. 1F).

In 2003, the Korea Asthma Allergy Foundation (KAF) was launched to promote the prevention and control of asthma and allergic diseases (Fig. 1G). In 2005, KAF became a founding member of Global Alliance of Chronic Respiratory Diseases (GARD). In 2007, the second general meeting of GARD was held in Seoul, at which time GARD Korea was launched (Fig. 1H).
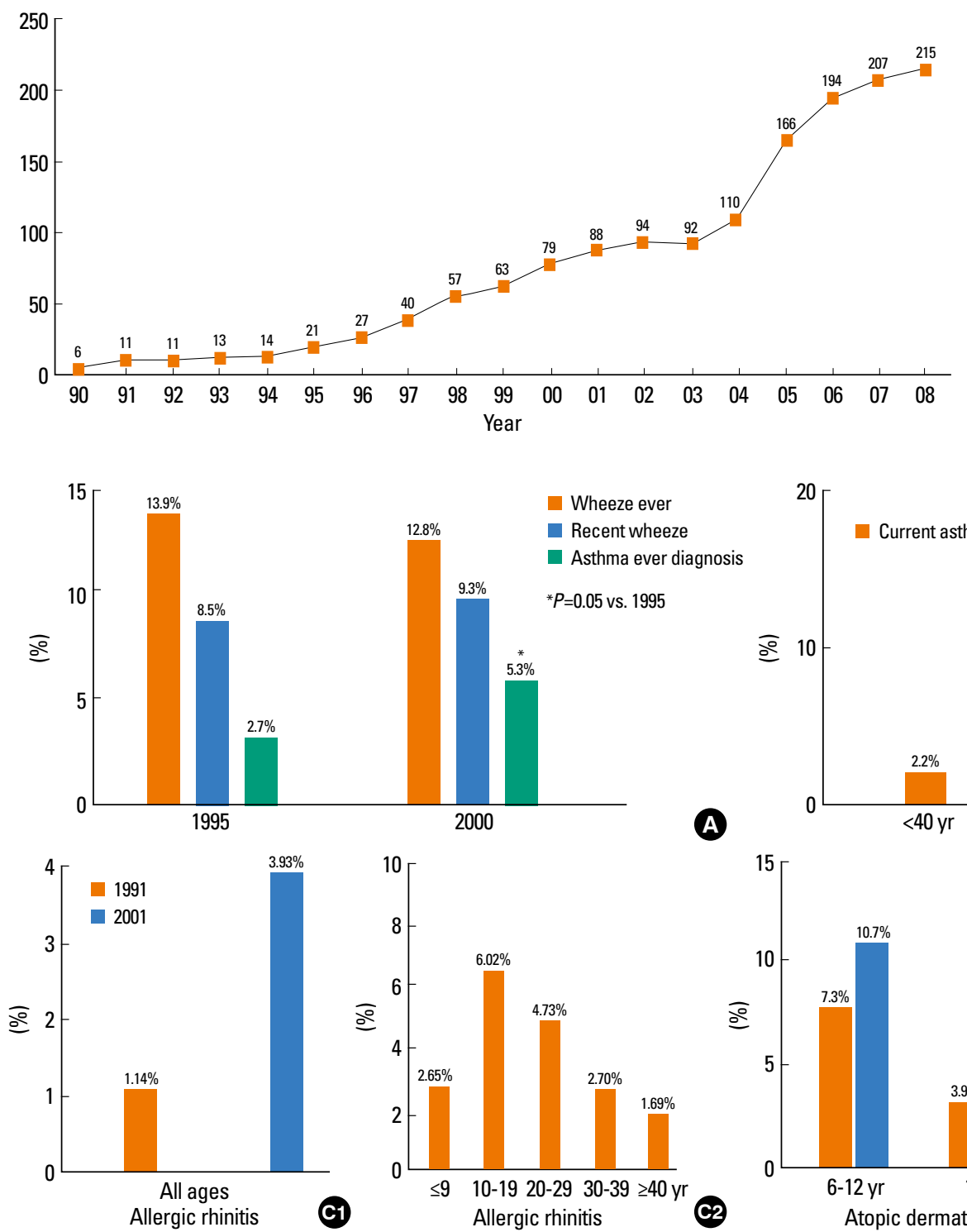

A
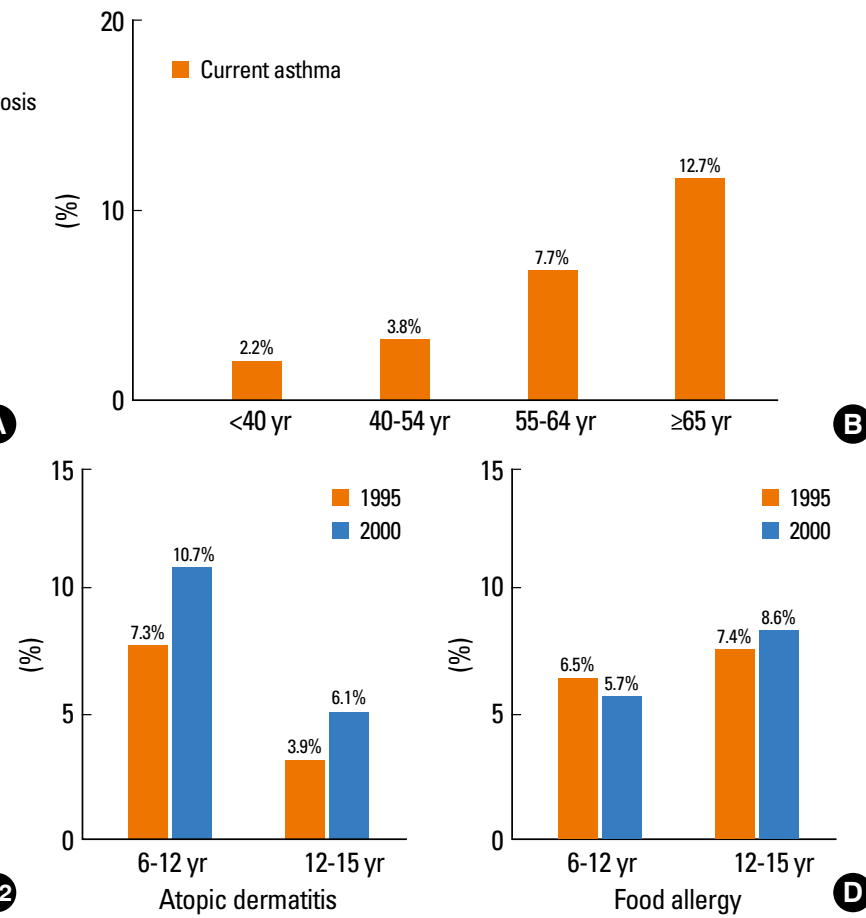

Fig. 2. Growth of Korean allergy SCI papers. These data were obtained from a PubMed search (keyword [allergy or asthma or hypersensitivity] and affiliation [Korea])

Fig. 3. Prevalence of asthma and allergic diseases based on epidemiologic studies in Korea. (A) Changes in the prevalence of asthma symptoms in Korean schoolaged children between 1995 and 2000. (B) Prevalence of current asthma according to age in Korean adults. (C) Prevalence of perennial allergic rhinitis, (C1) changes in prevalence between 1991 and 2001, (C2) prevalence according to age. (D) Prevalence of atopic dermatitis and food allergies based on questionnaires in Korean school-aged children. 


\section{ADVANCES IN THE FIELD}

Despite a short history, scientific research by Korean allergists has expanded quantitatively and qualitatively over the last three decades since the publication of the first Korean allergy SCI paper by Kim YY et al. ${ }^{1}$ in 1985 (Fig. 2). Currently, many Korean allergy investigators perform global-level scientific research and lead innovative projects in various fields of allergy research.

\section{Epidemiology}

Prevalence of asthma and allergic diseases

The prevalence of asthma in Korea has been reported in several large-scale studies since the 1990s and ranges from $2 \%$ to $13 \%$ according to different methodologies, case definitions, and study populations. ${ }^{2}$ Nationwide surveys performed in 1995 and 2000 using the International Study of Asthma and Allergies in Childhood (ISAAC) questionnaires showed that the prevalence of asthma diagnosis in middle school-aged children (12-15 years old) increased from $2.7 \%$ in 1995 to $5.3 \%$ in 2000 (Fig. 3A). ${ }^{3}$ During childhood, body mass index, passive smoking, living with a dog or cat, and residence in a large city were associated with a higher risk of wheezing. ${ }^{3}$ An epidemiologic study based on questionnaires and methacholine provocation tests in 7- to 19-yearold subjects in urban cities revealed that the prevalence of asthma was $4.6 \%{ }^{4}$

The prevalence of adult asthma based on the questionnaires and methacholine challenge tests increased according to increase of age, and interestingly, asthma prevalence was unexpectedly higher in the elderly group $(2.0 \%$ in < 40 -year-old, $3.8 \%$ in 40 - to 54 -year-old, $7.7 \%$ in 55 - to 64 -year-old, $12.7 \%$ in $>65$ year-old; Fig. 3B). ${ }^{5}$ The prevalence of perennial allergic rhinitis as diagnosed using clinical history and skin test (or MAST, RAST) to common inhalant allergen was $3.93 \%$. The highest values $(6.02$ \%) were observed in teenagers (10- to 19-year-old; Fig. 3C). ${ }^{6}$ The prevalence of atopic dermatitis also increased from $7.3 \%$ in 1995 to $10.7 \%$ in 2000 in 6- to 12-year-old and from $3.9 \%$ in 1995
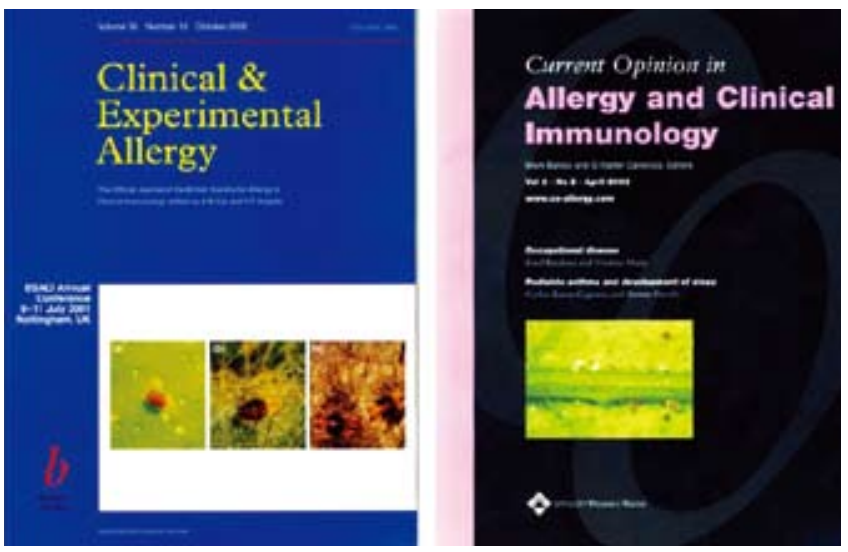

Fig. 4. Outdoor spider mites as novel allergens that cause asthma and allergic rhinitis as shown on the cover papers of international allergy journals. to $6.1 \%$ in 2000 in 12- to 15 -year-old children (Fig. 3D). ${ }^{7}$

\section{Allergens and occupational allergens in Korea}

Based on a nationwide survey, the most common inhalant allergens in Korea include the house dust mite (Dermatophagoides pteronyssinus, Dermatophagoides farinae), Tyrophagus putrescentiae, outdoor spider mites (Tetranychus urticae, Panonychus citiri), outdoor molds, indoor molds, cat fur, dog hair, German and American cockroaches, tree pollens, mugwort, and Japanese hop pollen. ${ }^{8}$ Geographical differences were observed and the sensitization rates of Japanese cedar pollen and Panonychus citri were especially high in the Jeju province, a southern island of Korea. ${ }^{8}$

Several important inhalant allergens have been reported in Korea. Outdoor spider mites, such as the citrus red mite (CRM; $P$. citiri), European red mite (ERM; P. ulmi), and two-spotted spider mite (TSM; T. urticae), are common allergens among fruitcultivating farmers (Fig. 4) ${ }^{9,10}$ Specifically, CRMs, first reported by Kim YK et al., ${ }^{11}$ are novel and important allergens that cause asthma and other allergic diseases among citrus cultivating farm and children living in rural areas. ${ }^{11-13}$ In addition, outdoor spite mites are a common sensitizing allergen associated with asthma and rhinitis symptoms in both rural and urban areas. ${ }^{14}$

Isocyanates including TDI, MDI, and HDI are common occupational allergens in Korea. Park HS et al., ${ }^{15-18}$ identified diisocyanate-conjugated protein and demonstrated the pathogenic role of specific IgG, as well as specific IgE, and the potential involvement of neutrophils and epithelial cells in TDI-induced asthma. ${ }^{15-18}$ Reactive dyes, ${ }^{19,20}$ herbal dusts such as ginseng and sanyak, ${ }^{21-24}$ deer hair ${ }^{25}$ and shell dust ${ }^{26}$ have been reported as unique occupational allergens in Korea.

\section{Asthma burden}

The death rate from chronic lower respiratory diseases including asthma between 1992 and 2007 increased from 12.9 (seventh leading cause of death) to 15.3 (sixth) deaths per 100,000 peo-

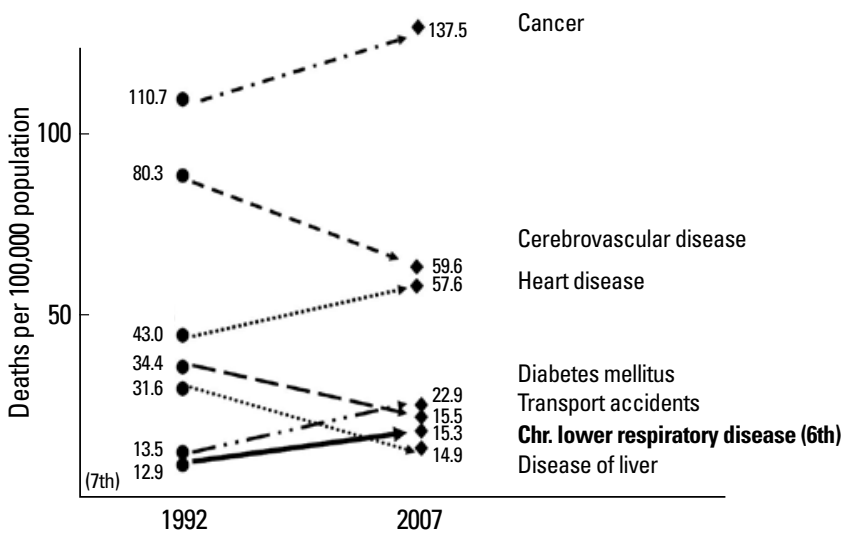

Fig. 5. Mortality rate and leading causes of death in Korea: changes between 1992 and 2007. 
ple (Fig. 5). Data from the Korean National Statistical Office and National Health Insurance Center (NHIC) suggest a growing economic burden of allergic diseases. The cost of asthma was estimated at over two billion dollars (the sum of direct and indirect costs) based on NHIC data and National survey on Health and Nutrition data in 2004 (Table 1).

Table 1. Socioeconomic burden of asthma in Korea (unit: million dollars)

\begin{tabular}{lcc}
\hline & HIRA data & NHIC data \\
\hline Direct cost & 573 & 962 \\
Indirect cost & 538 & 1,086 \\
Intangible cost $^{*}$ & 948 & 2,066 \\
Direct+Indirect & 1,112 & 2,048 \\
Total & 2,059 & 4,114 \\
\hline
\end{tabular}

HIRA, Health Insurance Review \& Assessment Service; NHIC, National Health Insurance Cooperation.

*Intangible cost means willingness to pay (WTP) for a month (not a year). WTP is usually evaluated higher than true value, but it is unclear how much is appropriate.
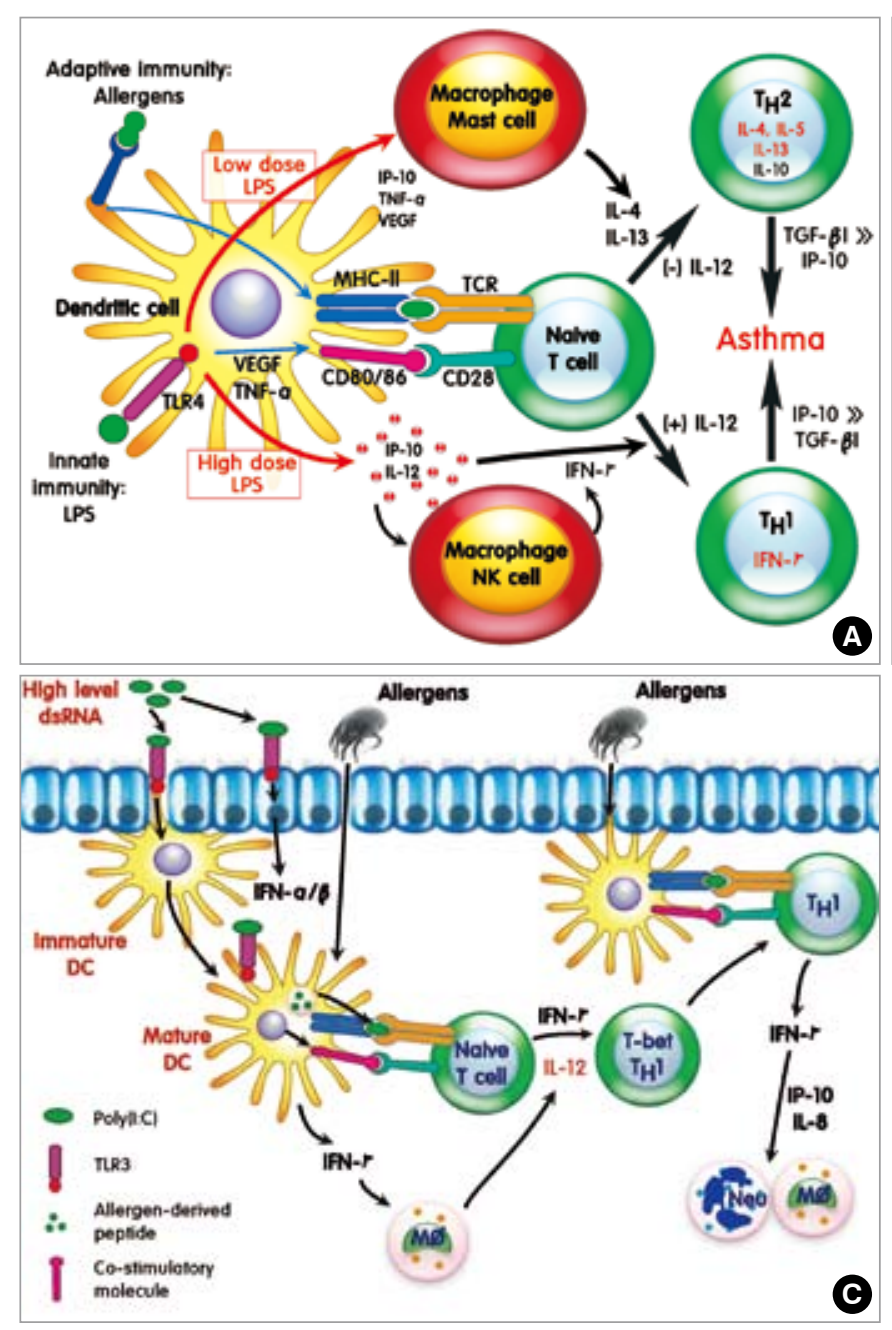

\section{Translational research}

Recently, numerous bidirectional translational investigations (bench to bedside and bedside to bench) on asthma and allergic diseases have been reported and are underway in Korea. Various studies using patient samples including blood, sputum, and tissue, and animal studies using allergic disease models, transgenic mice, and knockout mice are being performed to elucidate the pathogenesis of asthma and allergy, mechanisms of airway inflammation and remodeling, and new therapeutic modalities for asthma and allergy.

\section{Pathogenesis of asthma and allergy}

Pathologic findings from bronchial biopsy specimens of asthmatics investigated by Cho SH et al., ${ }^{27}$ revealed that airway inflammation and remodeling, such as loss of epithelial cells, infiltration of inflammatory cells (especially eosinophil), and increased subepithelial collagen deposition determines the severity of asthma. This study provides the valuable information that airway inflammation and remodeling are major pathologic features of asthma and are closely related to asthma severity.

Park CS et al., investigated the survival and apoptosis of eo-

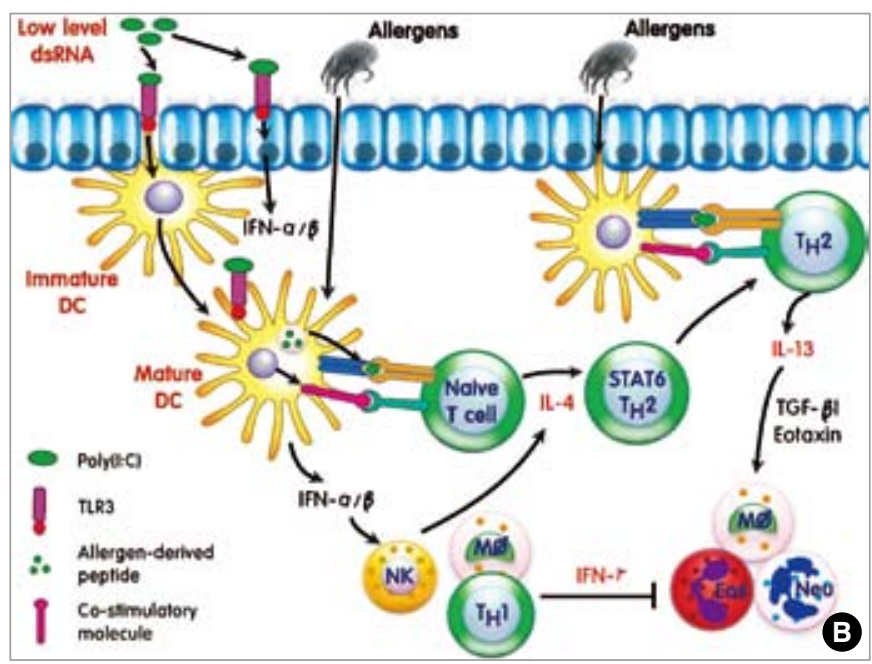

Fig. 6. Both Th1 and Th2 inflammation are involved in asthma pathogenesis. (A) Different asthma phenotypes according to the co-exposed dose of LPS with allergen. (B) Th2 airway inflammation induced by low-dose ds-RNA co-exposure with allergen. (C) Th1 airway inflammation induced by high-dose ds-RNA coexposure with allergen. 
sinophils isolated from the peripheral blood of atopic patients, ${ }^{28-30}$ and demonstrated that granulocyte macrophage colony-stimulating factor (GM-CSF) plays an important role in eosinophil survival in the asthmatic airway. ${ }^{28}$ In subsequent studies, the cAMP-dependent pathway and Bcl-2 expression were suggested to be involved in the regulation of eosinophil survival and apoptosis. ${ }^{29,30}$

\section{Immunologic mechanisms of asthma development}

Various types of asthma animal models expressing the heterogenous features of the human asthma phenotype have been developed and used for identifying the immunologic mechanism underlying asthma and evaluating the functional role of pathogenic molecules. ${ }^{31-33}$ Specifically, new animal models that are sensitized with allergens and natural environmental adjuvant factors via the intranasal route, not the intraperitoneal route, are pathophysiologically relevant and show similar characteristics to human allergen exposure and sensitization. Experimental asthma models of different phenotypes according to exposed levels of lipopolysaccharide (LPS) or double-stranded RNA (dsRNA) have led to a new paradigm of asthma pathogenesis, in which both Thl and Th2 inflammation are involved. ${ }^{31,32}$ These results also suggest a crucial role of the innate immune system in allergic airway inflammation and immune tolerance breakdown. Furthermore, studies examining mice deficient in toll-like receptor (TLR) 3, IL-13, IL-4, signal transducer and activator of transcription (STAT) 6, IFN- $\gamma$, and T-box expressed in T cells (Tbet) have elucidated the underlying pathophysiologic mechanisms of allergic lung inflammation development (Th1 and Th2 inflammation).$^{32}$ In these studies, the exposed doses of LPS and ds-RNA were an important factor in determining asthma phenotype; the high-dose LPS or ds-RNA model showed asthma features in which INF- $\gamma$ and Thl inflammation were dominant (Fig. 6). In fact, cytokine analysis of sputum from non-eosinophilic severe asthmatics showed enhanced INF- $\gamma$ mRNA expression, but not enhanced IL-4 expression. ${ }^{31}$

\section{Air pollution and infection in asthma pathogenesis}

The effects of air pollution and respiratory infections on asthma development have also been vigorously investigated. Childhood asthma prevalence studies that were performed in the industrialized urban city Yeocheon showed a higher prevalence of current wheezing (18.8\%) and airway hyperresponsiveness (AHR; 12.2\%) in industrial areas compared to residential areas (current wheezing, 9.0\%; AHR 7.5\%). ${ }^{34}$ The role of air pollution, which has been demonstrated in epidemiologic studies, has also been confirmed through in vivo animal studies. ${ }^{35,36}$

In a study by Park JK et al., repeated exposure to low-dose sulfur dioxide (SO2) in an ovalbumin (OVA)-induced asthma guinea pig model led to enhanced AHR and airway inflammation. ${ }^{35}$ This study indicated that exposure to air pollution, such as $\mathrm{SO} 2$, may lead to asthmatic reactions by enhancing sensitization to allergens. Jang AS et al., ${ }^{36}$ investigated the effects of ozone and diesel exhaust particulates (DEP) on asthma development and aggravation using an OVA-induced-asthma mouse model and found that the OVA-sensitized-challenged mouse exposed to ozone and DEP showed higher AHR and IL-4 and lower IFN- $\gamma$ levels in BAL fluid than the control and single exposure groups; co-exposure of ozone and DEP was suggested to have an additive effect on AHR by amplifying airway Th2 inflammation. ${ }^{36}$

LPS, a cell wall component of Gram-negative bacteria, and dsRNA, which is produced by many viruses and causes respiratory infection, are frequently encountered molecules in the environment. Experiments in asthma animal models using LPS or ds-RNA co-exposure with the allergens mentioned above have shown that respiratory infection and environmental factors are closely related to the development of asthma. In addition, the innate immune system plays a pivotal role in immunologic breakdown during asthma pathogenesis. ${ }^{31,32}$ The effects of viral infection, such as rhinovirus infection and respiratory syncytial virus (RSV) infection, on asthma development and exacerbation are also under investigation by several Korean researchers.

\section{New therapeutic modalities for asthma and allergies}

New therapeutic modalities through immunologic modulation including CpG oligodeoxynucleotides (CpG-ODNs) ${ }^{37}$ and recombinant basic fibroblast growth factor 2 (FGF2) ${ }^{38}$ have been investigated in asthma mouse models. Oligodeoxynucleotides containing a CpG motif are considered promising candidates for immune modulation in asthma because they are potent inducers of Thl immunity, enhance the production of IFN- $\gamma$ from OVA-specific T cells, and prevent the development of asthma in terms of AHR, airway eosinophilia, and OVA-specific IgE responses. ${ }^{37}$ Therefore, they are anticipated to provide an effective method for immune modulation of Th2 allergic asthma.

Kim YK et al., ${ }^{38}$ evaluated the biological roles of FGF2 in transforming growth factor-betal (TGF- $\beta 1$ ) over-expressing mice and the therapeutic effects of recombinant FGF2 in the development of asthma. AHR decreased in TGF- $\beta 1$ TG (+) mice and was accompanied by the up-regulation of FGF2 mRNA expression in the lung. However, AHR was markedly enhanced in TGF- $\beta 1(+)$ mice with homozygous FGF2 gene disruption. In this asthma mouse model, AHR, mucus production, and lung inflammation were inhibited markedly by rFGF2 treatment. ${ }^{38}$ These data suggest that FGF2 is a key inhibitor in the development of AHR, and rFGF2 treatment constrains the development of asthma phenotypes.

Responsiveness to corticosteroids and the role of TNF- $\alpha$ in Clamydia pneumonia infection was investigated by Cho YS et al., ${ }^{39}$ C. pneumoniae infection enhanced the proliferation and survival of immune and inflammatory cells and resulted in steroid resistance. These phenomena were reversed by the addition of a TNF- $\alpha$ inhibitor. These results suggest that TNF- $\alpha$ may play an important role in steroid resistance induced by atypical micro- 
bial respiratory infection. TNF- $\alpha$ inhibitors are therefore a candidate agent for managing steroid-resistant severe asthma. ${ }^{39}$

The cytoplasmic domain of CTLA-4, a negative regulator of Tcell activation, shows effective immunosuppressive properties that may be of potential use in the treatment of allergic asthma; its intranasal administration resulted in markedly reduced infiltration of inflammatory cells, secretion of Th2 cytokines, serum IgE levels, and AHR in a mouse model of allergic airway inflammation. ${ }^{40}$

\section{Genetic research}

Genetic studies of asthma and allergy susceptibility in Korea have been conducted through positional cloning and candidate gene association studies. ${ }^{41}$ Genome-wide association studies are being performed to elucidate genetic factors underlying asthma pathogenesis. ${ }^{42}$

\section{Genetic studies for asthma and asthma-related phenotypes}

Many genes and genetic polymorphisms associated with asthma and asthma-related phenotypes, such as atopy, IgE production, and AHR, were discovered by Korean allergy researchers. The genetic association of ADAM33 (disintegrin and metalloproteinase domain-containing protein 33 encoding gene), an asthma susceptibility gene, was replicated in a Korean population. ${ }^{43}$ The presence of the ADAM33 protein in bronchoalveolar lavage (BAL) fluids of asthmatics is associated with asthma development, and ADAM protein levels are related to asthma severity. ${ }^{44}$ The TNFA, IL3, IL5RA, CXCR3, PTGER3, PPARG, and eotaxin1 genes are also associated with asthma development. ${ }^{45-51}$ IL3, VEGFR2, and FCERIB genes show an association with atopy, ${ }^{46,52,53}$ and TNFA, RUNX1, and CD40 genes show an association with serum IgE production in asthma patient ${ }^{45,54,55}$ In addition, FCERIB, TNFA, and RANTES genes are associated with AHR. $^{56-58}$

The combined effects of genes such as TNFA+IL13 and TNFA+ $\mathrm{CD} 14$ on asthma susceptibility suggest that gene-gene interactions are involved in the pathogenic mechanisms of asthma. ${ }^{57,59}$ Multi-locus analysis using multifactor-dimensionality reduction (MDR) has also shown that gene-gene or gene-environmental interactions contribute to the development of allergy and asthma. ${ }^{60,61}$

\section{Pharmacogenomic studies}

The realization of personalized and tailored medicine is anticipated in the near future. Pharmacogenomics research will make it feasible to predict drug responses and adverse reactions of individuals. Pharmacogenomic research is mainly performed in the field of respiratory therapeutic drugs (bronchodilator, antileukotrienes, theophylline, and corticosteroids) and adverse drug reactions (antibiotics, aspirin, allopurinol, and anticonvulsant). The B2 adrenergic receptor gene (ADRB2) polymorphism is associated with anticholinergics (tiotropium) respons- es, as well as $\beta 2$ agonist responses. ${ }^{62,63}$ In addition, the $T B X A 2 R$ gene is associated with leukotriene receptor antagonism in Korean children with asthma. ${ }^{64}$

Genetic associations and gene markers for aspirin intolerance, including HLA-DPBI*0301, HLA-DB1*0609, ALOX5, CYSLT, $P G E 2, T B X A 2 R$, and FCER1A were identified in a Korean population by Park HS et al. ${ }^{65}$ Recently, the genetic interaction of CD 40 and CD40L, which are co-stimulatory danger-signal molecules of $\mathrm{T}$ cell activation, was reported to be associated with antibiotic-associated cutaneous hypersensitivity reactions. ${ }^{66}$

\section{Clinical studies}

Large-scale, multi-center cohort studies for asthma such as COREA (Cohort for Reality and Evolution of adult Asthma), ${ }^{67}$ elderly asthma cohorts, and childhood asthma cohorts have been designed since the early 2000s and are ongoing. Many Korean clinical researchers have participated in various international multi-center clinical trials and are involved in the clinical application of new drugs, diagnostics, and medical devices. In addition to large-scale trials, various types of clinical research, including asthma morbidity and patient insight surveys, ${ }^{2,68}$ outcome research, and investigator-initiated trials are being performed. Furthermore, Korean treatment guidelines have been developed and revised through systematic review by experts. ${ }^{69}$

\section{ACTIVITIES OF ALLERGY-RELATED SOCIETIES IN KOREA}

\section{Korean Academy of Asthma, Allergy and Clinical Immunology}

The Korean Academy of Asthma, Allergy and Clinical Immunology (KAAACI) was founded in 1972 and consists of physicians, pediatricians, dermatologists, otorhinolaryngologists, pathologists, and researchers who are interested in allergy and clinical immunology. It started with only 58 members, but now it has grown to 1225 members. The main activities of KAAACI include research communications (annual allergy congress, research work group, seminars, and symposia), publication of the Korean Journal of Allergy, Asthma and Clinical Immunology, guideline development, and educational workshops and lectures. In addition, the group has organized international communications such as joint meetings with the World Allergy Congress (WAC), Asia Pacific Congress of Allergy and Clinical immunology (APCACI), West Pacific Allergy Symposium (WPAS), Interasma, and Korea-Japan Joint Allergy Symposium.

\section{Korea Asthma Allergy Foundation}

The Korea Asthma Allergy Foundation (KAF) was founded for the purpose of supporting academic and research activities, public relations, and education related to the prevention of asthma and allergy. In addition, the KAF acts to promote the quality of life and health outcomes of patients. The main activities of the KAF include public relations (TV, newspaper, and magazine campaigns, World Asthma Day ceremony, seminars, and con- 
ventions on asthma/allergic diseases), education (patient education, asthma-friendly schools), research (burden of asthma, asthma morbidity and patient insight survey, guideline implementation) and international relationships as an active member of GARD. KAF contributed greatly to focussing the government's attention on asthma and allergic diseases, and the organization developed the nationwide asthma and atopic disease prevention and management plan (the Korean government has provided three million dollars annually since 2008).

The development of the Easy Asthma Management (EAM) program, a computer-assisted asthma management program, was one of the most innovative works of KAF. EAM provides an easily acceptable, simplified, and practical protocol that focuses on the diagnosis, treatment, and monitoring of asthma for general practitioners. The use of EAM is anticipated to facilitate the achievement of more successful clinical outcomes by filling the gaps between guidelines and actual practices. ${ }^{70,71}$

\section{CONCLUDING REMARKS: PERSPECTIVES OF ALLERGY IN KOREA}

The research and clinical capacity to understand and treat asthma and allergic diseases in Korea were improved remarkably in a brief time. Outstanding academic and scientific research has been performed in a variety of allergy research fields, including basic immunology, genomics and pharmacogenetics, new therapeutic target discovery, and clinical medicine. These multi-disciplinary allergy research resources are being integrated to identify allergic pathogenic mechanisms and curative treatments for allergy. The future directions of allergy research in Korea will focus on the pathogenic mechanisms of allergy (mechanisms of immunologic tolerance breakdown, the impact of the environment and climate change, role of extracellular vesicles in the development of allergy), the development of new therapeutic modalities (discovery of new therapeutic targets and immune modulation), and the realization of personalized medicine. The translation of scientific achievements to the bedside and society through the collaboration of researchers and health promotion activities will lead to better allergy and asthma control in Korea.

\section{REFERENCES}

1. Kim YY, Holgate ST, Church MK. Inhibition of histamine release from dispersed human lung and tonsillar mast cells by nicardipine and nifedipine. Br J Clin Pharmacol 1985;19:631-8.

2. Cho SH, Park HW, Rosenberg DM. The current status of asthma in Korea. J Korean Med Sci 2006;21:181-7.

3. Hong SJ, Lee MS, Sohn MH, Shim JY, Han YS, Park KS, Ahn YM, Son BK, Lee HB. Self-reported prevalence and risk factors of asthma among Korean adolescents: 5-year follow-up study, 1995-2000. Clin Exp Allergy 2004;34:1556-62.

4. Kim YY, Cho SH, Kim WK, Park JK, Song SH, Kim YK, Jee YK, Ha
MN, Ahn YO, Lee SI, Min KU. Prevalence of childhood asthma based on questionnaires and methacholine bronchial provocation test in Korea. Clin Exp Allergy 1997;27:761-8.

5. Kim YK, Kim SH, Tak YJ, Jee YK, Lee BJ, Park HW, Jung JW, Bahn JW, Chang YS, Choi DC, Chang SI, Min KU, Kim YY, Cho SH. High prevalence of current asthma and active smoking effect among the elderly. Clin Exp Allergy 2002;32:1706-12.

6. Min YG, Choi BY, Kwon SK, Lee SS, Jung YH, Kim JW, Oh SJ. Multicenter study on the prevalence of perennial allergic rhinitis and allergy-associated disorders. J Korean Med Sci 2001;16:697-701.

7. Oh JW, Pyun BY, Choung JT, Ahn KM, Kim CH, Song SW, Son JA, Lee SY, Lee SI. Epidemiological change of atopic dermatitis and food allergy in school-aged children in Korea between 1995 and 2000. J Korean Med Sci 2004;19:716-23.

8. Kim TB, Kim KM, Kim SH, Kang HR, Chang YS, Kim CW, Bahn JW, Kim YK, Kang HT, Cho SH, Park HS, Lee JM, Choi IS, Min KU, Hong CS, Kim NS, Kim YY. Sensitization rates for inhalant allergens in Korea; a multi-center study. J Asthma Allergy Clin Immunol 2003; 23:483-93. Korean.

9. Kim YK, Kim YY. Spider-mite allergy and asthma in fruit growers. Curr Opin Allergy Clin Immunol 2002;2:103-7.

10. Kim YK, Lee MH, Jee YK, Hong SC, Bae JM, Chang YS, Jung JW, Lee BJ, Son JW, Cho SH, Min KU, Kim YY. Spider mite allergy in applecultivating farmers: European red mite (Panonychus ulmi) and two-spotted spider mite (Tetranychus urticae) may be important allergens in the development of work-related asthma and rhinitis symptoms. J Allergy Clin Immunol 1999;104:1285-92.

11. Kim YK, Son JW, Kim HY, Park HS, Lee MH, Cho SH, Min KU, Kim YY. New occupational allergen in citrus farmers: citrus red mite (Panonychus citri). Ann Allergy Asthma Immunol 1999;82:223-8.

12. Kim YK, Son JW, Kim HY, Park HS, Lee MH, Cho SH, Min KU, Kim YY. Citrus red mite (Panonychus citri) is the most common sensitizing allergen of asthma and rhinitis in citrus farmers. Clin Exp Allergy 1999;29:1102-9.

13. Kim YK, Park HS, Kim HY, Jee YK, Son JW, Bae JM, Lee MH, Cho $\mathrm{SH}, \mathrm{Min} \mathrm{KU}, \mathrm{Kim}$ YY. Citrus red mite (Panonychus citri) may be an important allergen in the development of asthma among exposed children. Clin Exp Allergy 2001;31:582-9.

14. Kim TB, Kim YK, Chang YS, Kim SH, Hong SC, Jee YK, Cho SH, Min KU, Kim YY. Association between sensitization to outdoor spider mites and clinical manifestations of asthma and rhinitis in the general population of adults. J Korean Med Sci 2006;21:247-52.

15. Park HS, Kim HY, Nahm DH, Son JW, Kim YY. Specific IgG, but not specific IgE, antibodies to toluene diisocyanate-human serum albumin conjugate are associated with toluene diisocyanate bronchoprovocation test results. J Allergy Clin Immunol 1999;104:847-51.

16. Park HS, Jung KS, Kim HY, Nahm DH, Kang KR. Neutrophil activation following TDI bronchial challenges to the airway secretion from subjects with TDI-induced asthma. Clin Exp Allergy 1999; 29:1395-401.

17. Park HS, Cho SH, Hong CS, Kim YY. Isocyanate-induced occupational asthma in far-east Asia: pathogenesis to prognosis. Clin Exp Allergy 2002;32:198-204.

18. Ye YM, Kim CW, Kim HR, Kim HM, Suh CH, Nahm DH, Park HS, Redlich CA, Wisnewski AV. Biophysical determinants of toluene diisocyanate antigenicity associated with exposure and asthma. J Allergy Clin Immunol 2006;118:885-91.

19. Park HS, Kim YJ, Lee MK, Hong CS. Occupational asthma and IgE antibodies to reactive dyes. Yonsei Med J 1989;30:298-304. 
20. Park HS, Kim JW, Hong CS. The prevalence of specific IgE and IgG to reactive dye-human serum albumin conjugate in workers of a dye factory and neighboring factories. J Korean Med Sci 1991;6:63-8.

21. Lee SK, Cho HK, Cho SH, Kim SS, Nahm DH, Park HS. Occupational asthma and rhinitis caused by multiple herbal agents in a pharmacist. Ann Allergy Asthma Immunol 2001;86:469-74.

22. Lee JY, Lee YD, Bahn JW, Park HS. A case of occupational asthma and rhinitis caused by Sanyak and Korean ginseng dusts. Allergy 2006;61:392-3.

23. Hur GY, Park HJ, Kim HA, Ye YM, Park HS. Identification of Dioscorea batatas (sanyak) allergen as an inhalant and oral allergen. J Korean Med Sci 2008;23:72-6.

24. Kim KM, Kwon HS, Jeon SG, Park CH, Sohn SW, Kim DI, Kim SS, Chang YS, Kim YK, Cho SH, Min KU, Kim YY. Korean ginseng-induced occupational asthma and determination of IgE binding components. J Korean Med Sci 2008;23:232-5.

25. Nahm DH, Park JW, Hong CS. Occupational asthma due to deer dander. Ann Allergy Asthma Immunol 1996;76:423-6.

26. Kim WH, Lee SK, Lee HC, Hong CS, Huh KB, Lee WY, Lee SY. Shellgrinder's asthma. Yonsei Med J 1982;23:123-30.

27. Cho SH, Seo JY, Choi DC, Yoon HJ, Cho YJ, Min KU, Lee GK, Seo JW, Kim YY. Pathological changes according to the severity of asthma. Clin Exp Allergy 1996;26:1210-9.

28. Park CS, Choi YS, Ki SY, Moon SH, Jeong SW, Uh ST, Kim YH. Granulocyte macrophage colony-stimulating factor is the main cytokine enhancing survival of eosinophils in asthmatic airways. Eur Respir J 1998;12:872-8.

29. Chang HS, Jeon KW, Kim YH, Chung IY, Park CS. Role of cAMP-dependent pathway in eosinophil apoptosis and survival. Cell Immunol 2000;203:29-38.

30. Chung IY, Nam-Kung EK, Lee NM, Chang HS, Kim DJ, Kim YH, Park CS. The downregulation of $\mathrm{Bcl}-2$ expression is necessary for theophylline-induced apoptosis of eosinophil. Cell Immunol 2000; 203:95-102.

31. Kim YK, Oh SY, Jeon SG, Park HW, Lee SY, Chun EY, Bang B, Lee HS, Oh MH, Kim YS, Kim JH, Gho YS, Cho SH, Min KU, Kim YY, Zhu Z. Airway exposure levels of lipopolysaccharide determine type 1 versus type 2 experimental asthma. J Immunol 2007;178:5375-82.

32. Jeon SG, Oh SY, Park HK, Kim YS, Shim EJ, Lee HS, Oh MH, Bang B, Chun EY, Kim SH, Gho YS, Zhu Z, Kim YY, Kim YK. TH2 and TH1 lung inflammation induced by airway allergen sensitization with low and high doses of double-stranded RNA. J Allergy Clin Immunol 2007; 120:803-12.

33. Chang YS, Kim YK, Bahn JW, Kim SH, Park HW, Kim TB, Cho SH, Min KU, Kim YY. Comparison of asthma phenotypes using different sensitizing protocols in mice. Korean J Intern Med 2005;20:152-8.

34. Kim YK, Baek D, Koh YI, Cho SH, Choi IS, Min KU, Kim YY. Outdoor air pollutants derived from industrial processes may be causally related to the development of asthma in children. Ann Allergy Asthma Immunol 2001;86:456-60.

35. Park JK, Kim YK, Lee SR, Cho SH, Min KU, Kim YY. Repeated exposure to low levels of sulfur dioxide (SO2) enhances the development of ovalbumin-induced asthmatic reactions in guinea pigs. Ann Allergy Asthma Immunol 2001;86:62-7.

36. Jang AS, Choi IS, Takizawa H, Rhim T, Lee JH, Park SW, Park CS. Additive effect of diesel exhaust particulates and ozone on airway hyperresponsiveness and inflammation in a mouse model of asthma. J Korean Med Sci 2005;20:759-63.

37. Park Y, Chang YS, Lee SW, Cho SY, Kim YK, Min KU, Kim YY, Cho
$\mathrm{SH}$, Sung YC. The enhanced effect of a hexameric deoxyriboguanosine run conjugation to $\mathrm{CpG}$ oligodeoxynucleotides on protection against allergic asthma. J Allergy Clin Immunol 2001;108:570-6.

38. Jeon SG, Lee CG, Oh MH, Chun EY, Gho YS, Cho SH, Kim JH, Min KU, Kim YY, Kim YK, Elias JA. Recombinant basic fibroblast growth factor inhibits the airway hyperresponsiveness, mucus production, and lung inflammation induced by an allergen challenge. J Allergy Clin Immunol 2007;119:831-7.

39. Cho YS, Kim TB, Lee TH, Moon KA, Lee J, Kim YK, Lee KY, Moon HB. Chlamydia pneumoniae infection enhances cellular proliferation and reduces steroid responsiveness of human peripheral blood mononuclear cells via a tumor necrosis factor-alpha-dependent pathway. Clin Exp Allergy 2005;35:1625-31.

40. Choi JM, Ahn MH, Chae WJ, Jung YG, Park JC, Song HM, Kim YE, Shin JA, Park CS, Park JW, Park TK, Lee JH, Seo BF, Kim KD, Kim ES, Lee DH, Lee SK. Intranasal delivery of the cytoplasmic domain of CTLA-4 using a novel protein transduction domain prevents allergic inflammation. Nat Med 2006;12:574-9.

41. Park HS, Kim SH, Park CS. The role of novel genes in modifying airway responses in asthma. Curr Allergy Asthma Rep 2006;6:112-6.

42. Kim SH, Cho BY, Park CS, Shin ES, Cho EY, Yang EM, Kim CW, Hong CS, Lee JE, Park HS. Alpha-T-catenin (CTNNA3) gene was identified as a risk variant for toluene diisocyanate-induced asthma by genome-wide association analysis. Clin Exp Allergy 2009;39:203-12.

43. Lee JH, Park HS, Park SW, Jang AS, Uh ST, Rhim T, Park CS, Hong SJ, Holgate ST, Holloway JW, Shin HD. ADAM33 polymorphism: association with bronchial hyper-responsiveness in Korean asthmatics. Clin Exp Allergy 2004;34:860-5.

44. Lee JY, Park SW, Chang HK, Kim HY, Rhim T, Lee JH, Jang AS, Koh ES, Park CS. A disintegrin and metalloproteinase 33 protein in patients with asthma: Relevance to airflow limitation. Am J Respir Crit Care Med 2006;173:729-35.

45. Shin HD, Park BL, Kim LH, Jung JH, Wang HJ, Kim YJ, Park HS, Hong SJ, Choi BW, Kim DJ, Park CS. Association of tumor necrosis factor polymorphisms with asthma and serum total IgE. Hum Mol Genet 2004;13:397-403.

46. Park BL, Kim LH, Choi YH, Lee JH, Rhim T, Lee YM, Uh ST, Park HS, Choi BW, Hong SJ, Park CS, Shin HD. Interleukin 3 (IL3) polymorphisms associated with decreased risk of asthma and atopy. J Hum Genet 2004;49:517-27.

47. Chang HS, Kim JS, Lee JH, Cho JI, Rhim TY, Uh ST, Park BL, Chung IY, Park CS, Shin HD. A single nucleotide polymorphism on the promoter of eotaxinl associates with its mRNA expression and asthma phenotypes. J Immunol 2005;174:1525-31.

48. Cheong HS, Kim LH, Park BL, Choi YH, Park HS, Hong SJ, Choi BW, Park CS, Shin HD. Association analysis of interleukin 5 receptor alpha subunit (IL5RA) polymorphisms and asthma. J Hum Genet 2005;50:628-34.

49. Cheong HS, Park CS, Kim LH, Park BL, Uh ST, Kim YH, Lym GI, Lee JY, Lee JK, Kim HT, Ryu HJ, Han BG, Kim JW, Park C, Kimm K, Shin $\mathrm{HD}$, Oh B. CXCR3 polymorphisms associated with risk of asthma. Biochem Biophys Res Commun 2005;334:1219-25.

50. Park HW, Shin ES, Lee JE, Kim SH, Kim SS, Chang YS, Kim YK, Min $\mathrm{KU}, \mathrm{Kim}$ YY, Cho SH. Association between genetic variations in prostaglandin E2 receptor subtype EP3 gene (Ptger3) and asthma in the Korean population. Clin Exp Allergy 2007;37:1609-15.

51. Oh SH, Park SM, Lee YH, Cha JY, Lee JY, Shin EK, Park JS, Park BL, Shin HD, Park CS. Association of peroxisome proliferator-activated 
receptor-gamma gene polymorphisms with the development of asthma. Respir Med 2009;103:1020-4.

52. Park HW, Lee JE, Shin ES, Lee JY, Bahn JW, Oh HB, Oh SY, Cho SH, Moon HB, Min KU, Elias JA, Kim YY, Kim YK. Association between genetic variations of vascular endothelial growth factor receptor 2 and atopy in the Korean population. J Allergy Clin Immunol 2006; 117:774-9.

53. Kim ES, Kim SH, Kim KW, Park HS, Shin ES, Lee JE, Sohn MH, Kim KE. Involvement of Fc(epsilon)Rlbeta gene polymorphisms in susceptibility to atopy in Korean children with asthma. Eur J Pediatr 2009;168:1483-90.

54. Chae SC, Park BL, Park CS, Ryu HJ, Yang YS, Lee SO, Choi YH, Kim EM, Uh ST, Kim YH, Kim KK, Oh B, Chung HT, Kimm K, Shin HD. Putative association of RUNX1 polymorphisms with IgE levels in a Korean population. Exp Mol Med 2006;38:583-8.

55. Park JH, Chang HS, Park CS, Jang AS, Park BL, Rhim TY, Uh ST, Kim $\mathrm{YH}$, Chung IY, Shin HD. Association analysis of CD40 polymorphisms with asthma and the level of serum total IgE. Am J Respir Crit Care Med 2007;175:775-82.

56. Kim YK, Park HW, Yang JS, Oh SY, Chang YS, Shin ES, Lee JE, Kim S, Gho YS, Cho SH, Min KU, Kim YY. Association and functional relevance of E237G, a polymorphism of the high-affinity immunoglobulin E-receptor beta chain gene, to airway hyper-responsiveness. Clin Exp Allergy 2007;37:592-8.

57. Kim HB, Kang MJ, Lee SY, Jin HS, Kim JH, Kim BS, Jang SO, Lee YC, Sohn MH, Kim KE, Hong SJ. Combined effect of tumour necrosis factor-alpha and interleukin-13 polymorphisms on bronchial hyperresponsiveness in Korean children with asthma. Clin Exp Allergy 2008;38:774-80.

58. Sohn MH, Kim SH, Kim KW, Jee HM, Park HS, Kim KE. RANTES gene promoter polymorphisms are associated with bronchial hyperresponsiveness in Korean children with asthma. Lung 2008;186: 37-43.

59. Hong SJ, Kim HB, Kang MJ, Lee SY, Kim JH, Kim BS, Jang SO, Shin HD, Park CS. TNF-alpha (-308 G/A) and CD14 (-159T/C) polymorphisms in the bronchial responsiveness of Korean children with asthma. J Allergy Clin Immunol 2007;119:398-404.

60. Park HW, Shin ES, Lee JE, Kwon HS, Chun E, Kim SS, Chang YS, Kim YK, Min KU, Kim YY, Cho SH. Multilocus analysis of atopy in Korean children using multifactor-dimensionality reduction. Tho- $\operatorname{rax} 2007 ; 62: 265-9$.

61. Lee JH, Moore JH, Park SW, Jang AS, Uh ST, Kim YH, Park CS, Park BL, Shin HD. Genetic interactions model among Eotaxin gene polymorphisms in asthma. J Hum Genet 2008;53:867-75.

62. Cho SH, Oh SY, Bahn JW, Choi JY, Chang YS, Kim YK, Min KU, Kim YY. Association between bronchodilating response to short-acting beta-agonist and non-synonymous single-nucleotide polymorphisms of beta-adrenoceptor gene. Clin Exp Allergy 2005;35:1162-7.

63. Park HW, Yang MS, Park CS, Kim TB, Moon HB, Min KU, Kim YY, Cho SH. Additive role of tiotropium in severe asthmatics and Arg16Gly in ADRB2 as a potential marker to predict response. Allergy 2009;64:778-83.

64. Kim JH, Lee SY, Kim HB, Jin HS, Yu JH, Kim BJ, Kim BS, Kang MJ, Jang SO, Hong SJ. TBXA2R gene polymorphism and responsiveness to leukotriene receptor antagonist in children with asthma. Clin Exp Allergy 2008;38:51-9.

65. Palikhe NS, Kim SH, Park HS. What do we know about the genetics of aspirin intolerance? J Clin Pharm Ther 2008;33:465-72.

66. Kim SH, Lee JE, Jee YK, Kim YK, Park HS, Min KU, Park HW. Allelic variants of CD40 and CD40L genes interact to promote antibioticinduced cutaneous allergic reactions. Clin Exp Allergy 2009;39: 1852-6.

67. Kim TB, Park CS, Bae YJ, Cho YS, Moon HB. Factors associated with severity and exacerbation of asthma: a baseline analysis of the cohort for reality and evolution of adult asthma in Korea (COREA). Ann Allergy Asthma Immunol 2009;103:311-7.

68. Cho SH, Kim YK, Chang YS, Kim SS, Min KU, Kim YY. Asthma insights and reality in Korea. Korean J Med 2006;70:69-77. Korean.

69. The Korean Academy of Asthma, Allergy and Clinical Immunology. National guideline for the management of asthma. J Asthma Allergy Clin Immunol 1998;18:339-84. Korean.

70. Choi BW, Yoo KH, Jeong JW, Yoon HJ, Kim SH, Park YM, Kim WK, Oh JW, Rha YH, Pyun BY, Chang SI, Moon HB, Kim YY, Cho SH. Easy diagnosis of asthma: computer-assisted, symptom-based diagnosis. J Korean Med Sci 2007;22:832-8.

71. Cho SH, Jeong JW, Park HW, Pyun BY, Chang SI, Moon HB, Kim YY, Choi BW. Effectiveness of computer-assisted asthma management program on physician adherence to guideline. J Asthma. Forthcoming 2010. 